\title{
Determinants of sheep and goat meat consumption in Switzerland
}

\author{
Matteo Aepli, ${ }^{1,2^{*}}$ and Robert Finger ${ }^{3}$
}

\footnotetext{
* Correspondence: aepli@ethz.ch ${ }^{1}$ Agri-Food and Agri-Environmental Economics Group, Institute for Environmental Decisions, ETH Zurich, Zurich, Switzerland ${ }^{2}$ Agri-Food and Agri-Environmental Economics Group, Institute for Environmental Decisions, Sonneggstrasse 33, SOL E5, 8092 Zurich, Switzerland
}

\begin{abstract}
In this study, we estimated the influence of different meat prices, socio-demographic and geographic variables on sheep and goat meat demand using the Swiss household expenditure survey from 2000 to 2005, a micro data set on 20,940 households resident in Switzerland. This study is motivated by the fact that sheep and goats play a major economic role especially for small farms in Swiss agriculture and contribute to conservation of landscape and biodiversity especially in the mountain regions. Considering the high share of households with zero consumption for sheep and goat meat, we estimated a Tobit-model. Missing prices are replaced by monthly, regional market prices where possible, or by quality adjusted prices based on unit values. Our results show that pork is a substitute for sheep and goat meat, whereas beef is a complementary good, and that socio-demographic variables like education or the presence of children and geographic variables are important in determining demand of sheep and goat meat.
\end{abstract}

Keywords: Sheep and goat meat; Consumer demand; Tobit-Model

\section{Background}

In Switzerland, there are currently almost 418,000 sheep and 82,000 goats. This production activity has a high importance especially for small-scale farms and part-time farming in Swiss agriculture (Aepli and Jörin 2011). About 20\% of all Swiss farmers keep sheep or goats (SFSO 2012). The feeding system is mainly grassland based. Almost half of the sheep are grazing on summer pasture with increasing tendency during the last years (Kaulfers 2009). The production of these small ruminants contributes substantially to conservation of landscapes and diversity associated with Swiss and European agriculture (Dýrmundsson 2006). For instance, grazing of summer pastures prevents the natural regrowth of shrubs and forests (Herzog et al. 2009). Preventing this forest regrowth is of high societal and political interest because this is associated with negative impacts on biodiversity and the valuation of mountain landscapes by people (e.g., Gellrich et al. 2007; Hunziker et al. 2008). A recent investigation shows that this regrowth occurs particularly on steeper slopes and at higher elevations where cultivation costs are high and yield potential is low (Pellissier et al. 2012). These are, however, exactly the plots that are either only suitable for small ruminant grazing or where this land use implies the smallest costs of cultivating these areas (e.g., Dux et al. 2009). Thus, even though the consumption levels of sheep and goat meat are currently small (1.3 kg per capita for sheep and goat meat, Proviande 2012), small ruminants

(c) 2013 Aepli and Finger; licensee Springer. This is an Open Access article distributed under the terms of the Creative Commons Attribution License (http://creativecommons.org/licenses/by/2.0), which permits unrestricted use, distribution, and reproduction in any medium, provided the original work is properly cited. 
play a decisive role in Swiss agriculture. This role is determined by consumers' decisions to buy sheep and goat meat. ${ }^{\text {a }}$ Despite this relevance, there is no study that has addressed this question yet. ${ }^{\mathrm{b}}$ Switzerland as a high developed country is a particularly interesting case due to high production costs of farms for livestock and for crops on the one side (e.g., Lehmann et al. 2005; Lips et al. 2007; Raaflaub et al. 2005) and high purchase power of the consumers on the other side.

Against this background, the goal of this article is to identify the determinants of sheep and goat meat consumption in Switzerland. Sheep and goat farming are under great pressure in Switzerland as well as in the whole of Europe because of a decreasing demand, high imports from Oceania and a price drop in some countries in the recent past (Boutonnet 1999; Proviande 2013; Aepli and Jörin 2011).

An important reason for this consumption decline is the substitution with other types of meat like poultry and pork as well as fish (Dýrmundsson 2006; Jaquet et al.; 2000). Such substitution was also observed in Switzerland (Aepli and Jörin, 2011), where the consumer price for sheep meat increased by $30 \%$ since 2000, whereas the consumer price for poultry and fish has remained constant (SFSO, 2013).

During the next years international competition will further increase and at the same time sheep and goat meat consumption may continue to decline (Dýrmundsson 2006; European Commission 2012). Therefore, the understanding of the determinants of demand is crucial for the European sheep and goat meat production. The analysis of Swiss demand will give some useful information for the whole European market. Following recent studies (Abdulai 2002; Gallet 2009; Jaquet et al. 2000), we focused our research on the following determinants affecting sheep and goat meat consumption: different meat prices (sheep and goat, beef, pork, chicken), fish price, total expenditure and expenditure for food, as well as households' characteristics like the presence of children and education. In addition, we are also able to account for within-country cultural differences determined by language regions in Switzerland. Estimating the relevance of these determinants will contribute to a better understanding of the driving forces of demand and will provide an empirical base for marketing activities.

We use data from the Swiss household expenditure survey covering monthly data for the period 2000-2005 with a total sample size of 20,940. Even though the use of detailed micro-data (i.e., highly disaggregated data with respect to time, product groups and households) is superior to other approaches (e.g., Akbay et al. 2007; Lazaridis 2003; Majumder et al. 2012; Thiele 2008), we face two major methodological challenges when analyzing this household expenditure survey data for sheep and goat meat. First, many households do not purchase this kind of meat every month leading to a large share of zero observations. Second, no direct price data are provided in our data set. To overcome these problems we combine recently proposed approaches to a) avoid selection biases associated with zero consumption using Tobit regressions (e.g., Ma et al. 2006; Yimer 2011), and b) we derive quality adjusted price levels at the household level using the approach proposed by Majumder et al. (2012) or regional market prices where available.

\section{Methods}

Zero-consumption provides important behavioral information and has significant economic and econometric implications. The behavior of zero-consumption facing budget 
restrictions and prices is a typical corner solution of a household's utility maximization problem (Perali and Chavas 2000). This constitutes an econometric problem if food items are characterized by frequent zero-consumption, as it is the case for sheep and goat meat in Switzerland. As Deaton (1990) mentioned, a deletion of the zeroconsumption sample points could introduce bias and only allows to estimate conditional effects. To avoid selection bias we estimate a Tobit model (Tobin 1958; Amemiya 1984, 1973; Solon 2010) for censored regression which is widely used in singleequation models (e.g., Ma et al. 2006; Yimer 2011) and is of the following form:

$$
\mathrm{Y}_{\mathrm{i}}^{*}=\mathrm{f}\left(\mathrm{X}_{\mathrm{ij}} \beta_{j}\right)+\varepsilon_{\mathrm{i}} i=1, \ldots, n \text { and } j=1, \ldots, k
$$

Where $\mathrm{X}_{\mathrm{ij}}$ is a matrix consisting of $k$ explanatory variables for the $i$ th of $\mathrm{n}$ observations plus a vector of ones for the intercept term and $\beta_{j}$ is a vector of coefficients to be estimated with dimensions $(k+1) \times 1$. $\varepsilon_{\mathrm{i}}^{\prime}$ 's are independently, identically and normally distributed random variables with zero mean and variance $\sigma^{2}$, and $Y_{i}^{*}$ represents the latent variable. The relationship between $Y_{\mathrm{i}}^{\prime \prime}$ and $\mathrm{Y}_{\mathrm{i}}^{\prime}$ is defined as:

$$
Y_{i}= \begin{cases}0 & \text { if } Y_{i}^{*} \leq 0 \\ Y_{i}^{*} & \text { if } Y_{i}^{*}>0\end{cases}
$$

The Likelihood function for the observed sample of $\mathrm{Y}_{\mathrm{i}}^{\prime}$ 's is:

$$
\mathrm{L}=\prod \Phi\left(-\frac{\mathrm{f}\left(\mathrm{X}_{\mathrm{ij}} \beta_{j}\right)}{\sigma}\right)^{\left(1-\mathrm{I}_{\mathrm{i}}\right)} \frac{1}{\sigma} \phi\left(\frac{\left[\mathrm{Y}_{\mathrm{i}}-\mathrm{f}\left(\mathrm{X}_{\mathrm{ij}} \beta_{j}\right)\right]}{\sigma}\right)^{\mathrm{I}_{\mathrm{i}}}
$$

with $I_{i}=0$ for limited observations and $I_{i}=1$ otherwise. $\phi$ is the standard normal density function and $\Phi$ the cumulative counterpart. The parameters $\beta$ and $\sigma$ can be estimated consistently using maximum likelihood estimation. However, the maximum likelihood (ML) estimator is inconsistent and its use problematic if the assumptions of normality and homoscedasticity of the errors in the Tobit Model are violated (Amemiya 1984; Arabmazar and Schmidt 1981; Caudill and Mixon 2009; Li et al. 2007). To account for this high sensitivity of the ML estimator in the Tobit model with respect to the underlying assumptions, we corrected the standard errors with the Huber/White estimator (Huber 1967; White 1982). Because the estimated coefficients of the TobitModel refer to the latent variable, marginal effects are additionally calculated, which represent the effects of the explanatory variables on the expected value of the dependent variable evaluated at the mean values of the explanatory variables.

For beef, pork, veal and sheep and goat meat the Swiss Federal Office for Agriculture calculates monthly average consumer prices by regions which we take as market prices. For the other items (poultry meat and fish) missing information of price data were replaced using the approach presented in Majumder et al. (2012) who extended the approach of Cox and Wohlgenant (1986). They proposed to adjust unit values for the impact of quality and use them as market prices (see also e.g., Park et al. 1996; Thiele 2010). Unit values are obtained by dividing recorded expenditures for every household and food item by the corresponding quantity for every household. In contrast to the approach of Cox and Wohlgenant (1986), Majumder et al. (2012) and Hoang (2009) used regionally aggregated quality adjusted unit values as market prices based on the quality 
adjusted unit values for every household which is consistent with the hypothesis that households are facing the same price in the same market. We enhanced the approach by additionally aggregating over month and years.

The quality effects are mainly induced by income or total expenditure and household characteristics and can be determined as the difference between the unit value paid by the household and the regional average unit value. Therefore, the following equation holds:

$$
\begin{aligned}
& v_{\mathrm{i}}^{\text {hlym }}-\left(v_{\mathrm{i}}^{\text {lym }}\right)_{\text {median }} \\
& =\alpha_{\mathrm{i}} \mathrm{D}_{\mathrm{l}}+\beta_{\mathrm{i}} \mathrm{D}_{\mathrm{y}}+\gamma_{\mathrm{i}} \mathrm{D}_{\mathrm{m}}+\delta_{\mathrm{i}} \mathrm{x}^{\text {hlym }}+\eta_{\mathrm{i}} \mathrm{x}^{2 \mathrm{hlym}}+\theta_{\mathrm{i}} \mathrm{e}^{\text {hlym }}+\omega_{\mathrm{i}} \mathrm{f}_{\mathrm{i}}^{\text {hlym }}+\sum_{\mathrm{j}=1}^{\mathrm{n}} \mathrm{b}_{\mathrm{i}} \mathrm{Z}_{\mathrm{ij}}^{\text {hlym }}+\varepsilon_{\mathrm{i}}^{\text {hlym }}
\end{aligned}
$$

where $\mathrm{v}_{\mathbf{i}}^{\text {hlym }}$ is the unit value paid by household $h$ for item $i$ in its region $l$, year $y$, and month $\mathrm{m}$. For income, we include both income $(x)$ and the square of income $\left(x^{2}\right)$ to allow for a non-linear relationship between income and the unit value. $e$ is the household food expenditure, $f$ is the household expenditure for food consumed away from home (meals and beverages) and $Z_{i}$, denotes the $j$ th of $n$ household characteristics. This includes the household size by adult equivalent, which is generated following the OECD-modified equivalence scale (Hagenaars et al. 1994). Furthermore, binary dummy variables for having children and for having a university degree are included. $D_{i}, D_{y}$ and $D_{m}$ are dummies for region, year and month. We follow Majumder et al. (2012) and estimate equation (4) by using medians instead of means which is a more robust statistic with respect to outliers. Furthermore, we applied a robust M-estimator instead of ordinary least squares which limits the influence of outliers (see e.g., Finger 2013, for details).

After estimating (4) for each item with a sub-sample of the households which consumed the item, the region-, monthly-, and yearly-wise quality adjusted prices $p_{i}$ are generated by adding the median unit value $v_{i}^{\text {lym }}$ median for this item to the median of the estimated residuals from equation (4).

$$
\left(p_{i}^{l m y}\right)_{\text {median }}=\left(v_{i}^{l m y}\right)_{\text {median }}+\left(\varepsilon_{i}^{l m y}\right)_{\text {median }}
$$

Thus, the calculated market prices assigned to each household account for the households' region as well as month and year.

\section{Data and descriptive statistics}

The data used in this study are taken from the Swiss household expenditure survey for the period 2000-2005 that was conducted by the Swiss Federal Statistic Office. The Swiss household expenditure survey consists of repeated cross-sectional data with a periodicity of one month. Approximately 3,000 households participate every year. They are chosen at random from the register of private telephone lines. The sample is stratified by the seven major regions of Switzerland. The distribution of individuals is matched by a calibration method to the known distribution of the population and the sample is therefore representative for the Swiss population (see SFSO 2011, for details). In addition to expenditures, quantities bought, and income, the dataset also includes 
several household characteristic variables (e.g. household size, age and sex of the head of household).

The explanatory variables included in our model are prices for sheep and goat meat, for pork, beef, chicken and fish, total household expenditure and household expenditure for food, ${ }^{\mathrm{c}}$ household characteristics like the presence of children $(<=18$ years) and education (having a university degree or not), and dummies for the regions of Switzerland. ${ }^{\mathrm{d}}$ The total sample availbale to our study consists of $20^{\prime} 940$ households where $81.75 \%$ of the households did not consume sheep and goat meat during the recording period. Table 1 presents the 1\% trimmed mean values for the expenditure variables and the region dummies including the quantity purchased, which is used to calculate the unit values in the first stage of quality adjusted prices. ${ }^{e}$

Table 2 presents the results of pairwise t-tests to determine whether differences across regions with respect to expenditures (total and food) and sheep and goat consumption (consumption and expenditures) are significant.

The household data show that monthly expenditure in the French-speaking part of Switzerland for sheep and goat meat is with 6.48 Swiss francs significantly higher than in the German-speaking part of Switzerland, showing an average consumption of 3.05 Swiss francs per month. Households in the Italian speaking part of Switzerland spend

Table 1 Characteristics of the sample and descriptive statistics of sheep and goat meat consumption and household expenditure

\begin{tabular}{|c|c|c|c|c|}
\hline & $\begin{array}{l}\text { Total } \\
\text { Switzerland }\end{array}$ & $\begin{array}{l}\text { German-speaking } \\
\text { part of Switzerland }\end{array}$ & $\begin{array}{l}\text { French-speaking } \\
\text { part of Switzerland }\end{array}$ & $\begin{array}{l}\text { Italian-speaking } \\
\text { part of Switzerland }\end{array}$ \\
\hline \multirow{2}{*}{$\begin{array}{l}\text { Number of } \\
\text { households }\end{array}$} & 20940 & 14637 & 4497 & 1806 \\
\hline & $\begin{array}{l}\text { Mean in total } \\
\text { Switzerland } \\
\text { (1\% trimmed) }\end{array}$ & $\begin{array}{l}\text { Mean in the } \\
\text { German-speaking } \\
\text { part of Switzerland } \\
\text { (1\% trimmed) }\end{array}$ & $\begin{array}{l}\text { Mean in the } \\
\text { French-speaking } \\
\text { part of Switzerland } \\
\text { (1\% trimmed) }\end{array}$ & $\begin{array}{l}\text { Mean in the } \\
\text { Italian-speaking } \\
\text { part of Switzerland } \\
\text { (1\% trimmed) }\end{array}$ \\
\hline $\begin{array}{l}\text { Sheep and goat } \\
\text { meat consumed per } \\
\text { household and month } \\
\text { (in Swiss Francs) }\end{array}$ & 3.74 & 3.05 & 6.48 & 2.81 \\
\hline $\begin{array}{l}\text { Sheep and goat } \\
\text { meat consumed per } \\
\text { household and } \\
\text { month (in kg) }\end{array}$ & 0.12 & 0.09 & 0.23 & 0.11 \\
\hline $\begin{array}{l}\text { Household monthly } \\
\text { total expenditure } \\
\text { in CHF }\end{array}$ & 7811.18 & 7892.46 & 7869.05 & 7035.58 \\
\hline $\begin{array}{l}\text { Household monthly } \\
\text { expenditure for } \\
\text { food in CHF }\end{array}$ & 601.29 & 588.38 & 641.66 & 606.03 \\
\hline $\begin{array}{l}\text { Household size } \\
\text { in adult equivalents }\end{array}$ & 1.63 & 1.63 & 1.63 & 1.66 \\
\hline $\begin{array}{l}\text { Number of children } \\
(<=18 \text { years })\end{array}$ & 0.64 & 0.63 & 0.67 & 0.62 \\
\hline $\begin{array}{l}\text { Age of the household } \\
\text { reference person }\end{array}$ & 49.03 & 49.04 & 48.50 & 50.29 \\
\hline $\begin{array}{l}\text { Highest education } \\
\text { of the household } \\
\text { reference person* }\end{array}$ & 2.64 & 2.65 & 2.65 & 2.49 \\
\hline
\end{tabular}

*The education level is recorded with a scale from 1 to 3 , whereas 1 is compulsory school, 2 is professional education and 3 is higher professional education like a university degree. See SFSO (2011), for details on the data collection and the representativeness of the sample. 
Table 2 Pairwise comparison of the regional means for consumption of sheep and goat meat, total household expenditure and household expenditure for food using t-test

\begin{tabular}{lll}
\hline $\begin{array}{l}\text { Sheep and goat meat consumed per household and month } \\
\text { (in Swiss Francs) }\end{array}$ & $\begin{array}{l}\text { French-speaking } \\
\text { part of Switzerland }\end{array}$ & $\begin{array}{l}\text { Italian-speaking } \\
\text { part of Switzerland }\end{array}$ \\
\hline German-speaking part of Switzerland & $-15.55^{* * *}$ & 0.95 \\
French-speaking part of Switzerland & - & $-11.60^{* * *}$ \\
Sheep and goat meat consumed per household and month (in kg) & $-17.30^{* * *}$ & $-2.02^{*}$ \\
German-speaking part of Switzerland & - & $-9.86^{* * *}$ \\
French-speaking part of Switzerland & & \\
Household monthly total expenditure in CHF & 0.40 & $9.94^{* * *}$ \\
German-speaking part of Switzerland & - & $-8.43^{* * *}$ \\
French-speaking part of Switzerland & & \\
Household monthly expenditure for food in CHF & $-9.70^{* * *}$ & $-2.31^{*}$ \\
German-speaking part of Switzerland & - & $-4.09^{* * *}$ \\
French-speaking part of Switzerland & - &
\end{tabular}

T-values are presented in the table. ${ }^{*}$ and ${ }^{* * *}$ denote significance at $5 \%$ and $0.1 \%$ level, respectively.

statistically more on food in general but do not spend more on sheep and goat meat than households in the German speaking part of Switzerland.

\section{Results and Discussion}

Estimations of the Tobit-model are presented in Table 3. It shows that, as expected, rising prices for sheep and goat meat lead to a decline in its demand. Furthermore, we find sheep and goat meat to be substitutes to other meat. More specifically, an additional unit on price of pork would increase the household demand for sheep and goat meat by 0.38 units. In contrast, the negative sign for beef prices indicates that households facing a one unit lower beef price spend 0.20 units more on sheep and goat meat than households facing the higher beef price. In contrast, no significant influence of fish and chicken price levels on sheep and goat meat consumption has been found.

Table 3 Parameter estimates of the Tobit-model for the influence of the explanatory variables on the household expenditure for sheep and goat meat

\begin{tabular}{|c|c|c|c|}
\hline Independent variables & Coefficients & $\begin{array}{r}\text { Marginal } \\
\text { effect }\end{array}$ & $\begin{array}{r}\text { Robust } \\
\text { standard } \\
\text { error }\end{array}$ \\
\hline Sheep and goat meat price per kg in CHF & $-1.362^{*}$ & $-0.214^{*}$ & 0.598 \\
\hline Pork price per kg in CHF & $2.423^{* * *}$ & $0.380^{* * *}$ & 0.523 \\
\hline Beef price per kg in CHF & $-1.275^{* *}$ & $-0.200^{* *}$ & 0.410 \\
\hline Chicken price per kg in CHF & -0.153 & -0.024 & 0.266 \\
\hline Fish price per kg in CHF & -0.244 & -0.038 & 0.190 \\
\hline Household monthly total expenditure in CHF & $0.001^{* * *}$ & $0.000^{* * *}$ & 0.000 \\
\hline Household monthly expenditure for food in CHF & $0.055^{* * *}$ & $0.009^{* * *}$ & 0.005 \\
\hline Presence of children (yes $=1$, otherwise $=0$ ) & $-15.116^{* * *}$ & $-2.372^{* * *}$ & 1.939 \\
\hline University degree (university degree = 1, otherwise =0) & $9.902^{* * *}$ & $1.554^{* * *}$ & 1.618 \\
\hline $\begin{array}{l}\text { Household in the French-speaking region of Switzerland } \\
\text { (yes }=1 \text {, otherwise }=0 \text { ) }\end{array}$ & $20.187^{* * *}$ & $3.168^{* * *}$ & 1.968 \\
\hline $\begin{array}{l}\text { Household in the Italian-speaking region of Switzerland } \\
(\text { yes }=1 \text {, otherwise }=0 \text { ) }\end{array}$ & $-5.314^{*}$ & $-0.834^{*}$ & 2.505 \\
\hline
\end{tabular}


The finding that pork meat is a good substitute for sheep and goat meat is consistent with the conclusions in Jaquet et al. (2000) who estimated a linearized Almost Ideal Demand System to calculate price and income elasticities based on household expenditure data for Switzerland of 1998. In contrast to pork, the model estimates suggest that beef is a complementary good. These findings are in agreement with Tiffin et al. (2011), who estimated price elasticities for UK. We included also the price for fish and chicken in the model due to previous research of Jaquet et al. (2000) who reported relatively high substitution elasticity for Switzerland between sheep and goat meat and fish and chicken meat, respectively. In contrast to the previous findings we were not able to show that the prices of these two meat categories have a significant effect on the household expenditure for sheep and goat meat. Schluep Campo (2004) analyzed Swiss meat demand at the wholesale level using time series data for the time period January 1996 to December 2002 with a semiflexible Almost Ideal Demand System for sheep, beef, pork and poultry. With respect to sheep meat, she reported positive compensated price elasticities for poultry and pork but compensated price elasticities of almost zero for meat. This thus supports our findings that pork is a substitute for sheep meat while beef tends to be a complementary good.

The influence of the expenditure (total, food and meat) is highly significant. We find households with higher total expenditure or higher expenditure for food, to spend more on sheep and goat meat. This implies positive income elasticity for sheep and goat meat.

Furthermore, socio-demographic variables are found to be significant in affecting consumer demand for sheep and goat meat. This is consistent with other research findings (Dhraief et al. 2012; Gao and Spreen 1994; Lazaridis 2003). For the presence of children, the sign is negative; indicating that households with children consume a lower amount of sheep and goat meat ${ }^{\mathrm{f}}$. The marginal rate indicates a decrease in sheep and goat meat expenditure by $-2.37 \mathrm{CHF}$. Children have less strong preferences for sheep and goat meat. This is consistent with the results of a study for sheep meat consumption in Spain (Sepúlveda et al. 2011) - which probably also holds for goat meat - stating that young people consume sheep meat less frequently than older people, which may be caused by the influence of stereotypes, unfamiliarity and the strong flavor of sheep and goat meat (Karakuş 2006).

In contrast, education has been found to have a positive influence on sheep and goat meat consumption. If the head of the household has a university degree, the household spends a 1.6 CHF more on sheep and goat meat. The revealed influence of education on demand is in expectation with the findings of previous studies on meat consumption. Educational attainment is a main determinant in food consumption choices and is positively correlated with healthy dietary intake (Moreira and Padrão 2004). Sheep and goat meat has several health benefits in comparison to other red meat, especially if the animals are reared under extensive conditions on natural pastures like in Switzerland (zur Hausen 2012; Polidori et al. 2011), which also potentially coincides with advantages with respect to environmental impacts and animal welfare (Stott et al. 2005). As education is positively correlated with the awareness of these aspects associated with food consumption (Daniel et al. 2011; Monaco Bissonnette and Contento 2001), households with a better educated household head tend to have a higher demand for sheep and goat meat. 
Regional differences in sheep and goat meat consumption pattern in Switzerland are significant, especially for the French-speaking part of Switzerland in comparison to the German-part of Switzerland. Accounting for all the influences of the other variables in our regression, the marginal rates are 3.17 and -0.83 for the French-speaking and Italianspeaking part, respectively. This confirms earlier research showing that sheep and goat meat shows high level of spatial heterogeneity (e.g. in Aepli 2013), which is expected to be caused by different consumer attitudes towards sheep and goat meat (Sañudo et al. 2007) based on different cultural and traditional backgrounds (Karakuş 2006).

\section{Conclusions}

Our results suggest that prices for different meat categories, expenditure as well as different household characteristics and regional aspects are predominant factors determining the demand for sheep and goat meat in Switzerland. The coefficients in our Tobit model are all, except of the price for chicken and fish, statistically significant. Our results confirm earlier research that sheep and goat meat is a substitute to chicken and pork, but is complementary to beef. Our results allow some insights how to cope with future challenges for sheep and goat production in Switzerland. For instance, the positive sign for the French-speaking part of Switzerland implies that marketing activities should be especially focused on this area, where sheep and goat meat consumption is traditionally higher and well accepted by the consumers (LID 2000). One of the major challenges for Swiss sheep and goat producer will be price reductions resulting from trade liberalization between Switzerland and the European Union on the one hand and trade liberalization as a result of WTO negotiation on the other hand. Switzerland still has a highly restrictive border protection for agricultural products. This is particularly the case for meat, where the border protection consists of tariff-rate quotas. In the case of sheep and goat meat the quota is always exhausted. Above-quota imports are currently scarce, because the over-quota tariff is so high that it has normally a prohibitive effect on trade (Jörin and Lengwiler 2004). Thus, a relaxation of the highly restrictive tariff-rate quota along with liberalization steps, would probably lead imports to rise quickly (Schluep Campo 2004, Aepli and Jörin 2011). But, earlier research has also shown that Swiss consumers are willing to pay higher prices for highquality and domestically produced products (Bolliger 2012). Thus, the here indicated effects may offer a high-quality strategy as a potential path for Swiss sheep and goat producers. Our results suggest, for instance, that an improved communication of potential health and environmental benefits may help to cope with future challenges. But, a more detailed understanding of the determinants of demand is a core issue to intensify and tailor marketing activities and prevent Swiss as well as other European producers to suffer from a sharp price decline after a reduction of trade barriers. In addition, higher prices will encourage the production of small ruminant which could have direct positive effects on conservation of landscapes and biodiversity especially for summer pastures, which should be addressed in further research.

\section{Endnotes}

${ }^{a}$ Compared to other types of meat, sheep and goat meat have both a pronounced flavor. In comparison to sheep meat, goat meat tends to be darker red with a coarser texture (Webb et al. 2005, Gaili and Aili 1985). 
${ }^{\mathrm{b}}$ Along these lines, there are in general little research available identifying determinants of sheep and goat consumption (see e.g., Juma et al. (2010) or Bernabéu et al. (2012) for exceptions).

${ }^{c}$ Due to relatively low correlation between total expenditure and expenditure for food we included both variables in the model.

${ }^{\mathrm{d}}$ We first estimated the model with the factor variable month to capture seasonality. Since we calculate monthly prices for the meat categories there has been some multicollinearity between the variable month and the prices. Seasonality is partly captured by the price variables. We therefore decided to estimate the model without the variable month.

${ }^{\mathrm{e}}$ This method removes $1 \%$ of the largest and the smallest values before calculating the mean. We decided to use the trimmed mean instead of the normal mean, because we detect some outliers in the sample and this method is more robust with respect to possible outliers.

${ }^{\mathrm{f}}$ We started with a model also including household size. Due to some correlation of the variables especially between household size and the dummy for children, we tested the model in several specifications. In every specification the coefficients have the same sign, almost the same magnitude and significance. The qualitative interpretation remains the same.

\section{Competing interests}

The authors declare that they have no competing interests.

\section{Authors' contributions}

MA prepared the data, performed the statistical analysis and drafted the manuscript together with RF. RF participated in the design of the study and drafted the manuscript. All authors read and approved the final manuscript.

\section{Acknowledgements}

This research was conducted with support from the Swiss Federal Office for Agriculture within the project "Food demand analysis in Switzerland". We would like to thank anonymous reviewers for helpful comments and suggestions on an earlier version of the manuscript.

\section{Author details}

${ }^{1}$ Agri-Food and Agri-Environmental Economics Group, Institute for Environmental Decisions, ETH Zurich, Zurich Switzerland. ${ }^{2}$ Agri-Food and Agri-Environmental Economics Group, Institute for Environmental Decisions, Sonneggstrasse 33, SOL E5, 8092 Zurich, Switzerland. ${ }^{3}$ Agricultural Economics and Rural Policy Group Wageningen University Hollandseweg 1, Wageningen University, 6706 KN, Wageningen, The Netherlands.

Received: 22 February 2013 Accepted: 1 October 2013

Published: 09 October 2013

\section{References}

Abdulai A (2002) Household demand for food in Switzerland. A quadratic almost ideal demand system. Swiss J Econ Stat 138(1):1-18

Aepli M (2013) Schätzen von Engelkurven für verschiedene Fleischkategorien. Diploma thesis, ETH Zurich, Zurich

Aepli M, Jörin R (2012) Der Schweizer Lammfleischmarkt: Marktanalyse und Wettbewerb. ETH Zurich, Zurich. http://www.afee.ethz.ch/people/Staff/maepli/Publications/ Der_Schweizer_Lammfleischmarkt_Marktanalyse und Wettbewerb. Accessed 10 Dec 2012

Akbay C, Boz l, Chern WS (2007) Household food consumption in Turkey. Eur Rev Agri Econ 34(2):209-231

Amemiya T (1973) Regression analysis when the dependent variable is truncated normal. Econometria 41(6):997-1016

Amemiya T (1984) Tobit models: a survey. J Econ 24(1-2):3-61

Arabmazar A, Schmidt P (1981) Further evidence on the robustness of the Tobit estimator to heteroscedasticity. J Econ 17(2):253-258

Bernabéu R, Tendero A, Olmeda M (2012) Consumer preferences versus commercial differentiation: a Spanish case study. Brit Food J 114(11):1626-1639

Bolliger C (2012) Ökonomische Analyse von Herkunftsangaben bei Agrarerzeugnissen - Präferenz und Zahlungsbereitschaft für die "Herkunft Schweiz". Dissertation, ETH Zurich

Boutonnet JP (1999) Perspectives of the sheep meat world market on future production systems and trends. Small Ruminant Res 34(3):189-195

Caudill SB, Mixon FG (2009) More on testing the normality assumption in the Tobit Model. J Appl Stat 36(12):1345-1352 

Commission, Brussels

Cox TL, Wohlgenant MK (1986) Prices and quality effects in cross-sectional demand analysis. Am J Agri Econ 68(4):908-919

Daniel CR, Cross AJ, Koebnick C, Rashmi S (2011) Trends in meat consumption in the United States. Public Health Nutr 14(4):575-583

Deaton A (1990) Price elasticities from survey data: Extensions and Indonesian results. J Econ 44(3):281-309

Dhraief MZ, Oueslati M, Dhehibi B (2012) Meat and fish demand in Tunisia: economic and socio-demographic factors effects. Paper presented at the International Association of Agricultural Economists Conference 2012, Foz do Iguacu

Dux D, Matz K, Gazzaring C, Lips M (2009) Was kostet offenes Grünland im Berggebiet? Agrarforschung 16(1):10-15

Dýrmundsson OR (2006) Sustainability of sheep and goat production in North European countries - From the Arctic to the Alps. Small Ruminant Res 62(3):151-157

Finger R (2013) Investigating the performance of different estimation techniques for crop yield data analysis in crop insurance applications. Agri Econ 44(1):217-230

Gaili ES, Aili AE (1985) Meat from Sudan desert sheep and goats: Part 2 - composition of the muscular and fatty tissue. Meat Sci 13(4):229-236

Gallet CA (2009) Meat meets Meta: a quantitative review of the price elasticity of meat. Am J Agri Econ 92(1):258-272

Gao XM, Spreen T (1994) A Microeconometric Analysis of the U.S. Meat Demand. Canad J Agri Econ 42(3):397-412

Gellrich M, Baur P, Koch B, Zimmermann NE (2007) Agricultural land abandonment and natural forest re-growth in the Swiss mountains: a spatially explicit economic analysis. Agri Ecosyst Environ 118(1-4):93-108

Hagenaars AJM, De Vos K, Zaidi MA (1994) Poverty Statistics in the Late 1980s: Research Based on Micro-data. Kontoret for De Europæiske Fællesskabers Officielle. Publikationer, Luxembourg

Herzog F, Böni R, Lauber S, Schneider M, Seidl I (2009) AlpFUTUR - an inter- and transdisciplinary research program on the future of summer pastures in Switzerland. Paper presented at the 15th meeting of the FAO-CIHEAM Mountain Pastures Network, Agroscope Changins-Wadenswil Research Station ACW, Les Diablerets

Hoang LV (2009) Estimation of food demand from household survey data in Vietnam. Depocen Working Paper Series, no. $2009 / 12$

Huber PJ (1967) The behavior of maximum likelihood estimated under nonstandard conditions. Paper presented at the Fifth Berkeley Symposium on Mathematical Statistics and Probability. University of California Press, Berkeley. 1967

Hunziker M, Felber P, Gehring K, Buchecker M, Bauer N, Kienast F (2008) Evaluation of landscape change by different social groups. Mount Res Dev 28(2):140-147

Jaquet P, Abdulai A, Rieder P (2000) Empirische Analyse des Nahrungsmittelverbrauchs in der Schweiz: Ein dreistufiges LA/AIDS Modell. ETH Zurich, Zurich

Jörin R, Lengwiler Y (2004) Learning form financial markets: auctioning tariff-rate quotas in agricultural trade. Swiss J Econ Stat 140(4):521-541

Juma GP, Ngigi M, Baltenweck I, Drucker AG (2010) Consumer demand for sheep and goat meat in Kenya. Small Ruminant Res 90(1-3):135-138

Karakus F (2006) Consumer preferences on sheep and goat meat in the world. Paper presented at the 57th Annual Meeting of the European Association for Animal Production, Antalya, Turkey

Kaulfers C (2009) Weide- und Bewegungsverhalten von Schaf und Ziege auf der Alp und dessen Einfluss auf den Knochen- und Energiestoffwechsel. Dissertation, University of Zurich, Zurich

Lazaridis P (2003) Household meat demand in Greece: a demand systems approach using micro data. Agribusiness 19(1):43-59

Lehmann B, Gerwig C, Huber R (2005) Wettbewerbsfähigkeit der Schweizerischen Schweine- und Geflügelproduktion ETH Zurich, Zurich. http://www.bell.ch/Portaldata/1/Resources/6_Medien/Dossier_Wettbewerbsfaehigkeit/ dossier_wettbewerbsfaehigkeit_studie_eth.pdf. Accessed 18 Dec 2012

Li L, Simonoff JS, Tsai CL (2007) Tobit model estimation and sliced inverse regression. Stat Model 7(2):107-123

LID (2000) Lammfleisch: Die gefragten Stücke kommen hauptsächlich aus Übersee. In: Mediendienst Nr. 2460. Landwirtschaftlicher Informationsdienst. http://www.lid.ch/de/medien/mediendienst/artikel/infoarticle/8989/. Accessed 17 Nov 2012

Lips M, Ammann H, Signer A, Steingruber E (2007) Kostenvergleich im Ackerbau zwischen der Schweiz und Baden-W ürttemberg. ART-Berichte, Forschungsanstalt Agroscope Reckenholz-Tänikon, Ettenhausen

Ma H, Huang J, Fuller F, Rozelle S (2006) Getting rich and eating out: consumption of food away from home in urban China. Canad J Agri Econ 54(1):101-119

Majumder A, Ray R, Sinha K (2012) Calculating rural-urban food price differentials from unit values in household expenditure surveys: a comparison with existing methods and a new procedure. Am J Agri Econ 94(5):1218-1235

Monaco Bissonnette M, Contento IR (2001) Adolescents' perspectives and food choice behaviors in terms of the environmental impacts of food production practices: application of a psychosocial Model. J Nutr Educ 33(2):72-82

Moreira PA, Padrão PD (2004) Educational and economic determinants of food intake in Portuguese adults: a cross sectional survey. BMC Public Health 4:58

Park LJ, Holcomb RB, Raper KC, Capps O (1996) A demand system analysis of food commodities by U.S. households segmented by income. Am J Agri Econ 78(2):290-300

Pellissier L, Anzini M, Maiorano L, Dubuis A, Pottier J, Vittoz P, Guisan A (2012) Spatial predictions of land-use transitions and associated threats to biodiversity: the case of forest regrowth in mountain grasslands. Appl Veget Sci 16(2):227-236

Perali F, Chavas J-P (2000) Estimation of censored demand equations form large cross-section data. Am J Agri Econ 82(4):1022-1037

Polidori P, Ortenzi A, Vincenzetti S, Beghelli D (2011) Dietary properties of lamb meat and human health. Medit J Nutri Metab 4(1):53-56

Proviande (2012) Der Fleischmarkt im Überblick 2011. Proviande, Bern

Proviande (2013) Der Fleischmarkt im Überblick 2012. Proviande, Bern

Raaflaub M, Durgiai B, Genoni M (2005) Wettbewerbsfähigkeit der tierischen Veredelung in der Schweiz. School of Agricultural, Forest and Food Science, Zollikofen. http://www.vsf-mills.ch/Portaldata/1/Resources/vsf_vgs_internet/ 0510_WettbewerbsfaehigkeitSchlussbericht_neu_D.pdf. Accessed 18 Dec 2012 
Sañudo C, Alfonso M, San Julián R, Thorkelsson G, Valdimarsdottir T, Zygoyiannis D, Stamataris C, Piasentier E, Mills C, Berge P, Dransfield E, Nute GR, Enser M, Fisher AV (2007) Regional variation in the hedonic evaluation of lamb meat from diverse production systems by consumers in six European countries. Meat Sci 75(4):610-621

Schluep Campo I (2004) Market Options in the WTO Doha Round impacts on the Swiss meat market. Disseration, ETH Zurich

Sepúlveda WS, Maza MT, Pardos L (2011) Aspects of quality related to the consumption and production of lamb meat. Consumer versus producers. Meat Sci 87(4):366-372

SFSO (2011) Haushaltsbudgeterhebung 2005. Swiss Federal Statistical Office, Neuchâtel

SFSO (2012) Statistisches Lexikon der Schweiz, Landwirtschaftliche Betriebsstrukturerhebung. Swiss Federal Statistical Office, Neuchâtel. http://www.bfs.admin.ch/bfs/portal/en/index.html. Accessed 7 Dec 2012

SFSO (2013) Landesindex der Konsumentenpreise. Swiss Federal Statistical Office, Neuchâtel

Solon G (2010) A simple microeconomic foundation for a Tobit model of consumer demand. Econ Lett 106(2):131-132

Stott AW, Milne CE, Goddard PJ, Waterhouse A (2005) Projected effect of alternative management strategies on profit and animal welfare in extensive sheep production systems in Great Britain. Livestock Prod Sci 97(2):161-171

Thiele S (2008) Elastizitäten der Nachfrage privater Haushalte nach Nahrungsmitteln - Schätzung eines AIDS auf Basis der Einkommens- und Verbrauchsstichprobe 2003. Agrarwirtschaft 57(5):258-268

Thiele S (2010) Erhöhung der Mehrwertsteuer für Lebensmittel: Budget- und Wohlfahrtseffekte für Konsumenten. J Econo Stat 230(1):115-130

Tiffin R, Balcombe K, Salois M, Kehlbacher A (2011) Estimating Food and Drink Elasticities. University of Reading, Reading. https://www.gov.uk/government/uploads/system/uploads/attachment_data/file/137726/defra-stats-foodfarm-foodprice-elasticities-120208.pdf. Accessed 17 Dec 2012

Tobin J (1958) Estimation of relationships for limited dependent variables. Econometrica 26(1):24-36

Webb EC, Casey NH, Simela L (2005) Goat meat quality. Small Ruminant Res 60(1-2):153-166

White $H$ (1982) Maximum likelihood estimation of misspecified models. Econometrica 50(1):1-25

Yimer S (2011) Determinants of food consumption expenditure in Ethiopia. Int J Econ Res 2(5):151-165

zur Hausen $\mathrm{H}$ (2012) Red meat consumption and cancer: reasons to suspect involvement of bovine infectious factors in colorectal cancer. Int J Cancer 130(11):2475-2483

doi:10.1186/2193-7532-1-11

Cite this article as: Aepli and Finger: Determinants of sheep and goat meat consumption in Switzerland. Agricultural and Food Economics 2013 1:11

Submit your manuscript to a SpringerOpen ${ }^{\circ}$ journal and benefit from:

- Convenient online submission

- Rigorous peer review

- Immediate publication on acceptance

- Open access: articles freely available online

- High visibility within the field

- Retaining the copyright to your article

Submit your next manuscript at $\boldsymbol{\nabla}$ springeropen.com 